\title{
PERAN KELUARGA PENDIRI DALAM MENCIPTAKAN KINERJA KEUANGAN DAN NILAI PASAR PERUSAHAAN PADA PERUSAHAAN KELUARGA
}

\author{
Dewi Ariani \\ Email : Dewi.ariani9@gmail.com \\ Noorlaily Fitdiarini SE., MBA \\ Email : noorlailyf@yahoo.com \\ Departemen Manajemen Fakultas Ekonomi dan Bisnis Universitas Airlangga
}

\begin{abstract}
This study objective is to understand the effect involvement of founder family to financial performance (ROA) and firm market value (Tobins Q) in family firm which is listed in BEl (Bursa Efek Indonesia). Data obtain from annual reports and daily stock price which is publish between 2008 until 2013. Sample of this study included 33 family firm and 198 observation with purposive random sampling. This study use multiple linier regression method to test the effect of founder as an independent variable and control variables which is contain size, age and risk, towards firm financial performance (ROA) and firm market value (Tobins $Q$ ) as dependent variables. The result suggest that involvement of founder family has significant negative effect towards ROA and Tobins $Q$. This result show that family firm which managed by founder family tend to have smaller financial performance and firm market value.
\end{abstract}

Key Words : Family firm, Founder, ROA, dan Tobins $Q$

\section{PENDAHULUAN}

Perusahaan keluarga (family business) merupakan fenomena tersendiri dalam dunia bisnis, selain jumlahnya yang sangat banyak, perusahaan jenis ini juga memiliki andil yang cukup signifikan bagi pendapatan negara. Menurut Biro Pusat Statistik perusahaan keluarga di Indonesia mempunyai kontribusi besar terhadap PDB, yaitu mencapai 82,44 persen (Tantangan Perusahaan Kelvarga di Era Bisnis Modern, 2012). Anderson dan Reeb (2003) serta Campbell dan Minguez-Vera (2008) menyebutkan bahwa dalam perusahaan keluarga sering terjadi pendelegasian posisi manajemen puncak kepada anggota keluarga, sehingga semakin besar persentase anggota dewan yang mempunyai hubungan keluarga dalam perusahaan. Di Indonesia, sebagian besar posisi penting dalam perusahaan dikuasai oleh anggota keluarga, seperti pada PT Ciputra Surya, enam dari delapan yang menjabat sebagai dewan direksi adalah anggota keluarga dari pendiri yaitu $\operatorname{Dr}(\mathrm{HC})$ Ir. Ciputra.

Hasil keputusan akhir perusahaan masih bergantung pada kebijakan keluarga. Hal ini sesuai dengan apa yang disebutkan oleh Susanto, et al. (2007:182) bahwa pada mayoritas perusahaan (82\%), pemimpin perusahaan yang bukan anggota keluarga akan meminta persetujuan dari anggota keluarga yang terlibat dalam perusahaan. Melihat kondisi tersebut maka dapat diprediksi bahwa perusahaan keluarga dapat mengurangi biaya agensi karena tidak jarang pada perusahaan keluarga, pihak manajemen atau dewan direksi merupakan keluarga pendiri, sehingga perusahaan dapat menyelaraskan antara kepentingan manajemen dengan pemilik perusahaan. 


\section{Dewi Ariani \\ Noorlaily Fitdiarini}

Kinerja keuangan dan nilai pasar perusahaan merupakan dua hal yang sangat penting bagi perusahaan dalam kelangsungan hidupnya, agar mampu berkembang dan bersaing dengan perusahaan lain. Uniknya di perusahaan keluarga pencapaian profit harus beriringan dengan keharmonisan keluarga, karena bisnis keluarga dikatakan sukses apabila mampu menciptakan profit dan terus berkembang seiring dengan semakin harmonisnya keluarga. Keluarga pendiri sangat berperan dalam menciptakan nilai dan kinerja perusahaan karena keluarga pendiri memiliki keterikatan psikologis yang kuat dan komitmen terhadap organisasi daripada orang lain (Arthurs dan Busenitz, 2003). Perusahaan akan menunjukkan kinerja dan nilai yang semakin baik apabila ada keterlibatan dari pendiri ataupun keluarganya karena pendiri cenderung menunjukkan kebutuhan yang lebih tinggi untuk berprestasi. Di sisi lain, pemilik non pendiri tidak selalu memiliki komitmen dan track record seperti yang dimiliki oleh pemilik dari keluarga pendiri.

Terdapat beberapa perusahaan keluarga yang menjual perusahaannya kepada orang lain yang bukan anggota keluarga. Hal tersebut disebabkan oleh beberapa keadaan, diantaranya karena ingin mengembangkan bisnisnya yang lain, bisnisnya sudah berada pada ambang kehancuran atau pendirinya sudah meninggal akan tetapi anggota keluarganya tidak ada yang ingin melanjutkan bisnis tersebut. Sehingga munculah perusahaan keluarga yang dikelola bukan dari anggota keluarga pendiri. Perusahaan yang sudah bukan menjadi milik keluarga pendiri, secara otomatis sudah tidak ada keterlibatan keluarga pendiri di dalam perusahaan tersebut baik itu dalam bentuk kepemilikan maupun keterlibatan di dalam posisi dewan komisaris dan posisi dewan direksi karena sudah dikuasai oleh pemilik yang baru. Dengan berpindahnya perusahaan dari keluarga pendiri ke bukan pendiri dikhawatirkan dapat menurunkan kinerja dan nilai perusahaan karena meningkatnya biaya agensi dan kurangnya komitmen dari pemilik serta masalah yang dihadapi pemilik karena tidak seberapa paham dengan keadaan perusahaan. Hal tersebut sesuai dengan hasil penelitian yang dilakukan oleh Hamberg, et al,. (2013) bahwa kinerja dan nilai perusahaan keluarga yang dikelola non pendiri secara signifikan lebih buruk daripada perusahaan keluarga pendiri dan kinerja tidak berbeda dengan perusahaan lain.

Beberapa penelitian menyatakan bahwa keterlibatan keluarga pendiri dalam pengelolaan perusahaan dapat berpengaruh positif bagi kinerja keuangan dan nilai pasar perusahaan seperti Hamberg ef al,. (2013), akan tetapi tidak menutup kemungkinan akan terjadi sebaliknya bahwa keterlibatan keluarga pendiri juga dapat membawa dampak negatif bagi perusahaan. Seperti yang dikemukakan oleh Anderson dan Reeb, 2003; Villalonga dan Amit, 2006 bahwa keluarga pendiri dengan tulus mengabdikan diri untuk perusahaan mereka dan cenderung kepada kepemilikan terkonsentrasi, dengan demikian ada risiko bahwa pendiri akan mengekstrak manfaat pribadi atau membuat keputusan ekonomi yang mengatasnamakan pemegang saham minoritas.

Kinerja keuangan (ROA) dan nilai pasar perusahaan (Tobins Q) merupakan dua hal yang berbeda. Kinerja keuangan menggambarkan kondisi yang dilihat dari kondisi internal perusahaan, nilai pasar perusahaan merupakan kondisi yang dinilai dari persepsi pihak eksternal (investor). Perusahaan yang memiliki kinerja keuangan baik belum tentu memiliki nilai perusahaan yang baik pula. Akan tetapi jika perusahaan memiliki nilai pasar yang baik maka sudah pasti memiliki kinerja kevangan yang baik pula karena tidak ada investor yang menilai perusahaan itu baik jika memiliki kinerja keuangan yang buruk. Maka dari itu peneliti 
membedakan antara kinerja keuangan dan nilai perusahaan pada pasar. Sehingga penelitian ini dilakukan untuk mengetahui seberapa besar pengaruh kelvarga pendiri terhadap kinerja keuangan dan nilai pasar perusahaan.

\section{LANDASAN TEORI}

\section{Perusahaan Keluarga}

Pengertian perusahaan keluarga menurut John L. Ward dan Craig E. Aronoff (2002), suatu perusahaan kelvarga dinamakan perusahaan keluarga apabila terdiri dari dua atau lebih anggota kelvarga yang mengawasi keuangan perusahaan. Sedangkan menurut Robert G. Donnelley (2002), suatu organisasi dinamakan perusahaan keluarga apabila paling sedikit ada keterlibatan dua generasi dalam kelvarga tersebut dan mereka mempengaruhi kebijakan perusahaan. Menurut Villalonga dan Amit (2006) sebagian besar definisi tentang perusahaan keluarga setidaknya mencakup tiga dimensi, yaitu: satu atau beberapa kelvarga memegang bagian penting dari modal perusahaan; anggota keluarga mempertahankan kendali yang besar pada perusahaan (misalnya, distribusi modal dan hak suara) dengan kemungkinan pembatasan undang-undang atau hukum; dan anggota keluarga berada pada posisi manajemen puncak.

Proporsi kepemilikan keluarga sangat beragam, akan tetapi penulis menggunakan acuan dari penelitian Andres (2008) yang mengkategorikan perusahaan keluarga dalam dua kriteria yaitu a) pendiri atau anggota keluarga memiliki saham sebesar $25 \%$ atau lebih; dan b) terdapat anggota keluarga yang menduduki kursi dewan komisaris atau dewan direksi jika saham yang dimiliki kurang dari $25 \%$. Hal ini sama dengan yang tertera pada Keputusan Direksi PT Bursa Efek Jakarta Nomor: Kep-305/BEJ/07-2004, peraturan nomor I-A tentang pencatatan saham dan efek bersifat ekuitas selain saham yang diterbitkan oleh perusahaan tercatat pada point I.15 menyebutkan bahwa pemegang saham pengendali adalah pemegang saham yang memiliki $25 \%$ atau lebih saham perusahaan, atau pemegang saham yang memiliki kemampuan dengan cara apapun mempegaruhi pengelolaan dan/ atau kebijaksanaan perusahaan meskipun jumlah saham yang dimiliki kurang dari $25 \%$.

Terdapat dua jenis perusahaan keluarga di dunia, seperti yang sebutkan oleh Susanto, et al. (2007:4) dalam artikel The Jakarta Consulting Group bahwa dalam terminologi bisnis, ada dua jenis perusahaan keluarga, yaitu, (1) Family Owned Entreprise (FOE) merupakan perusahaan yang dimiliki oleh keluarga tetapi dikelola oleh manajemen profesional yang berasal dari luar lingkaran anggota kelvarga. Anggota keluarga dapat mengoptimalkan fungsinya sebagai pengawas, (2) Family Business Enterprise (FBE) merupakan perusahaan yang dimiliki dan dikelola oleh anggota keluarga pendirinya. Jadi baik pemilik maupun pengelola dipegang oleh pihak yang sama, yaitu keluarga. Pada penelitian ini, peneliti lebih fokus kepada model perusahaan keluarga tipe kedua yaitu Family Business Enterprise (FBE) karena sesuai dengan kondisi yang ada di Indonesia.

Menurut Ward (2004) dalam Susanto et al., (2007:12) menyatakan bahwa perusahaan keluarga memiliki keuntungan dan kekurangan. Kelebihan dari perusahaan keluarga, antara lain, (1) kesempatan bekerja sama, (2) saling percaya memperteguh keluarga dan bisnis, (3) kesempatan untuk menciptakan kekayaan, (4) sebagai cara untuk menurunkan nilai-nilai kepada anak-anak, (5) respek di masyarakat, dan (6) pengaruh yang lebih besar sebagai individu. Sedangkan kekurangan dari perusahaan kelvarga, antara lain, (1) potensi munculnya konflik, (2) munculnya kekecewaan ketika tujuan pribadi tidak tercapai, (3) terlalu 


\section{Dewi Ariani \\ Noorlaily Fitdiarini}

banyak masalah financial, (3) hilangnya privasi yang disebabkan oleh publisitas, dan (4) rentan terhadap kritik dari luar keluarga.

\section{Teori Keagenan}

Dalam konteks manajemen keuangan, hubungan agen yang utama ada dua, antara lain :

1. Antara pemegang saham dengan manajer

Pada umumnya manajer hanya memiliki sebagian kecil dari saham perusahaan yang ada, hal tersebut mendorong keputusan-keputusan yang dilakukan manajer tidak untuk meningkatkan kesejahteraan pemegang saham akan tetapi untuk keuntungan pribadi seperti memikirkan gaji serta kebutuhan akan barang mewah, dan mereka menyumbangkan dana perusahaan untuk nama baik mereka, tetapi atas beban pemegang saham lainnya (Brigham dan Houston, 2001:22-26).

2. Antara pemegang saham mayoritas dengan minoritas

Di samping konflik antara pemegang saham dan manajer, ada juga konflik antara pemegang saham mayoritas dan minoritas (Shleifer dan Vishny, 1997). Konflik tipe ini sering terjadi pada saat salah satu anggota keluarga menjabat sebagai manajer perusahaan. Masalah timbul ketika manajer hanya memikirkan kepentingan keluarga, sehingga mengabaikan kepentingan saham minoritas (Chu, 2009).

Pada beberapa perusahaan keluarga di Indonesia, pendiri mendelegasikan keturunannya atau anggota keluarganya untuk memimpin perusahaan keluarga sehingga diharapkan perusahaan dapat menyelaraskan antara kepentingan manajer dengan pemilik perusahaan. Dengan terlibatnya keluarga pendiri sebagai pihak manajemen maka diharapkan dapat mengurangi konflik keagenan agar perusahaan tidak banyak mengeluarkan biaya keagenan untuk menyelesaikan konflik keagenan.

\section{Variabel Independen dan Kontrol}

Keluarga Pendiri. Seseorang yang mewujudkan bisnis dari adanya suatu peluang disebut pendiri perusahaan. Menurut Susanto et al, . (2007:23) Perusahaan keluarga di Indonesia, pada awal mulanya didirikan oleh single fighter. Selebihnya menggandeng mitra yang masih termasuk dalam close-circle family atau immediate family, seperti suami/istri, saudara, hingga teman dekat. Dalam penelitian ini, pendiri di proksikan dengan Found. found dapat dihitung dengan menggunakan variabel dummy yang membedakan antara perusahaan keluarga yang dikelola oleh keluarga pendiri dan perusahaan keluarga yang dikelola oleh keluarga bukan pendiri. Bernilai 1 jika dikelola oleh keluarga pendiri dan bernilai 0 jika dikelola oleh kelvarga bukan pendiri.

Size. Ukuran perusahaan digunakan karena menunjukkan kapasitas dan kemampuan perusahaan dalam mengelola segala aktivitas operasionalnya dan keuangannya demi mencapai tujuan perusahaan. Ukuran perusahaan dapat dihitung dengan menggunakan Ln (total asset perusahaan).

Age. Age digunakan untuk mengetahui umur perusahaan dari awal mula perusahaan berdiri hingga penelitian ini dilakukan. Hal ini juga salah satu penentu investor dalam mengambil keputusan dalam melakukan investasi.

Risk. Variabel risiko dalam penelitian ini digunakan untuk mengetahui tingkat risiko yang akan diterima oleh investor. Risiko dapat diukur dengan menggunakan standar deviasi dari return saham yang dimiliki perusahaan. 


\section{Variabel Dependen}

Kinerja keuangan digunakan oleh pihak manajemen untuk melihat dan menilai kondisi keuangan serta kinerja perusahaan dari sisi profitabilitas. Terdapat beberapa rasio profitabilitas, salah satunya adalah Return On Assets. Menurut Sudana (2011: 22) Return on Asset menunjukkan kemampuan perusahaan dengan menggunakan seluruh aktiva yang dimiliki untuk menghasilkan laba setelah pajak. Semakin besar rasio ini berarti semakin efisien perusahaan tersebut dalam menggunakan aktivanya. Penelitian ini hanya mengukur kinerja keuangan dengan menggunakan Return on Assets (ROA), karena ROA dapat mencerminkan efektivitas dan efisien perusahaan dalam mengelola seluruh asetnya. Return on Asset dinyatakan dengan rasio berikut :

$$
\text { ROA }=\underline{\text { Laba Bersih Setelah Pajak }}
$$

Total Aset

Nilai pasar mencerminkan tinggi rendahnya nilai pasar dari saham beredar. Menurut Ross (2013), terdapat beberapa rasio untuk mengukur nilai pasar perusahaan. Dua rasio yang relevan adalah market to book ratio dan Tobins $Q$ ratio. Secara konsep, Tobins $Q$ lebih baik untuk mengukur nilai pasar perusahaan daripada market to book ratio karena Tobins $Q$ berfokus kepada nilai perusahaan sekarang dibandingkan dengan seberapa besar biaya untuk mengganti asetnya sekarang. Semakin besar variabel ini menunjukkan semakin besar nilai pasar suatu perusahaan. Tobins $Q$ dinyatakan dengan rasio berikut :

Tobins $Q=$ Nilai Pasar Ekuitas + Total Utang

Total Aset

*Nilai Pasar Ekuitas $=$ (Harga saham akhir tahun $\mathrm{X}$ Jumlah saham yang beredar)

\section{Hipotesis}

Berdasarkan latar belakang, rumusan masalah, landasan teori, dan beberapa penelitian sebelumnya, maka hipotesis yang disusun dalam penelitian ini adalah sebagai berikut :

$\mathrm{H} 1$ : Perusahaan yang dikelola oleh keluarga pendiri berpengaruh positif terhadap kinerja perusahaan.

H2 : Perusahaan yang dikelola oleh keluarga pendiri berpengaruh positif terhadap nilai perusahaan.

\section{METODOLOGI PENELITIAN}

\section{Pendekatan Penelitian, Data, dan Sampel}

\section{Pendekatan Penelitian, Data dan Sampel}

Pada penelitian ini digunakan pendekatan kuantitatif untuk menjawab rumusan masalah. Sedangkan berdasarkan sumber perolehan data, data yang digunakan adalah data sekunder yang berupa laporan tahunan perusahaan dan laporan keuangan yang telah terdaftar di Bursa Efek Indonesia pada tahun 2008 2013 (dapat diperoleh dari www.idx.co.id.)

Prosedur pengumpulan data dalam penelitian ini adalah :

1. Studi kepustakaan

Studi kepustakaan merupakan pencarian data melalui studi pustaka dengan mempelajari referensi melalui buku-buku, jurnal, dan penelitian terdahulu yang berkaitan dengan penelitian yang sedang dilakukan.

2. Data melalui media internet 


\section{Dewi Ariani \\ Noorlaily Fitdiarini}

Pengumpulan melalui media internet dilakukan jika data yang dibutuhkan tidak dapat ditemukan melalui dua prosedur sebelumnya.

Populasi yang digunakan dalam penelitian ini adalah perusahaan keluarga yang terdaftar di Bursa Efek Indonesia (BEI) selama periode 2008-2013. Sedangkan pengambilan sampel dilakukan dengan menggunakan metode purposive sampling yakni pengambilan sampel dengan kriteria atau batasan-batasan tertentu. Adapun pertimbangan yang diambil berdasarkan tujuan penelitian yaitu sampel harus memenuhi kriteria sebagai berikut :

1. Perusahaan keluarga yang telah terdaftar di Bursa Efek Indonesia selama periode 2008-2013.

2. Perusahaan tidak bergerak dalam sektor keuangan maupun pendanaan seperti bank, asuransi, leasing, dan sekuritas.

3. Perusahaan memiliki data-data lengkap yang dibutuhkan dalam penelitian selama periode penelitian 2008-2013.

4. Perusahaan dapat dikategorikan termasuk dalam perusahaan pendiri atau non pendiri dan sejarah berdirinya harus jelas.

Perusahaan yang tergolong dalam perusahaan keluarga dapat dikategorikan sebagai berikut (Andres, 2008), Kepemilikan saham $25 \%$ atau lebih oleh anggota keluarga atau kelompok keluarga. Jika kepemilikan saham yang dimiliki oleh anggota keluarga atau kelompok keluarga kurang dari 25\%, maka anggota keluarga ikut terlibat dalam perusahaan dengan menduduki kursi dewan komisaris atau dewan direksi. Hubungan kelvarga dapat dicirikan dengan nama belakang atau nama keluarga yang sama antara pemilik saham dengan anggota dewan komisaris atau direksi.

\section{Pengukuran dan Definisi Operasional Variabel}

Definisioperasionaldarimasing-masingvariabeladalahsebagaiberikut:

Definisi operasional dan rumus perhitungan dari masing-masing variabel yang akan digunakan pada penelitian ini adalah sebagai berikut :

1. ROA (Return On Assets)

ROA merupakan variabel untuk mengukur seberapa besar perusahaan menghasilkan laba setelah pajak atau kinerja keuangan dari seluruh asset yang dimilikinya. ROA ini dapat diukur dengan rumus (2.4)

2. Tobins $Q$

Tobins Q merupakan variabel untuk mengukur seberapa besar perusahaan menciptakan nilai pasar. Tobins $Q$ dapat diukur dengan rumus (2.5)

3. Found

Found merupakan variabel independen yang berupa variabel dummy yang membedakan antara perusahaan keluarga yang dikelola dan dimiliki keluarga pendiri bernilai 1 dan bernilai 0 jika dimiliki dan dikelola bukan dari keluarga pendiri.

4. Size

Merupakan variabel yang mengukur besar kecilnya suatu perusahaan serta menggambarkan tingkat kekayaan yang dimiliki suaatu perusahaan dilihat dari total asset yang dimiliki perusahaan. Size dapat diukur dengan rumus (2.1) 
5. Age

Age merupakan variabel untuk mengetahui seberapa besar umur perusahaan dari awal mula perusahaan berdiri hingga penelitian ini dilakukan. Age dapat diukur dengan rumus (2.2)

6. Risk

Risk digunakan untuk mengetahui tingkat risiko yang akan diterima oleh investor. Risk dapat diukur dengan rumus (2.3)

\section{Metode Analisis Data}

Teknik analisis yang digunakan dalam penelitian ini adalah analisis regresi linier berganda (multiple regression). Penelitian ini menggunakan model analisis regresi sebagai berikut :

$R O A_{i, t}=a_{0}+\beta_{1}\left(\right.$ Found $_{i, t}+\beta_{2}(\text { Size })_{i, t}+\beta_{3}(\text { Age })_{i, t}+\beta_{4}(\text { Risk })_{i, t}+\varepsilon_{i, t}$

Tobins $Q_{i, t}=a_{0}+\beta_{1}\left(\right.$ Found $_{i, t}+\beta_{2}(\text { Size })_{i, t}+\beta_{3}(\text { Age })_{i, t}+\beta_{4}(\text { Risk })_{i, t}+\varepsilon i, t$

\section{HASIL DAN PEMBAHASAN}

Sampel dalam penelitian ini adalah perusahaan kelvarga yang terdaftar di Bursa Efek Indonesia selama periode 2008 hingga 2013. Berdasarkan kriteria pemilihan sampel yang telah dijelaskan sebelumnya dalam bab III, maka diperoleh sampel akhir sebanyak 33 perusahaan.

\section{Analisis Model}

Descriptive Statistics

\begin{tabular}{|l|l|l|l|l|l|}
\hline & N & Minimum & Maximum & Mean & Std. Deviation \\
\hline Roa & 198 & -.154 & .363 & .07042 & .068279 \\
Tobinsa & 198 & .291 & 9.876 & 1.54705 & 1.212569 \\
Found & 198 & 0 & 1 & .82 & .387 \\
Size & 198 & 25.609 & 31.558 & 28.47908 & 1.208126 \\
Age & 198 & 7 & 102 & 31.89 & 17.078 \\
Risk & 198 & .000 & .162 & .04294 & .029043 \\
Valid N (listwise) & 198 & & & & \\
\hline
\end{tabular}

*pada level of significant $5 \%$

Berdasarkan hasil uji asumsi klasik, model analisis telah memenuhi asumsi BLUE. Berikut adalah hasil uji asumsi klasik :

\section{Tabel Hasil Uji Autokorelasi}




\section{Dewi Ariani}

\section{Noorlaily Fitdiarini}

\begin{tabular}{|l|r|r|r|r|r|}
\hline Model & $R$ & $R$ Square & \multicolumn{1}{c|}{$\begin{array}{c}\text { Adjusted R } \\
\text { Square }\end{array}$} & $\begin{array}{c}\text { Std. Error of } \\
\text { the Estimate }\end{array}$ & $\begin{array}{c}\text { Durbin- } \\
\text { Watson }\end{array}$ \\
\hline 1 & $.474 \mathrm{a}$ & .224 & .208 & .060756 & 2.013 \\
\hline
\end{tabular}

a. Predictors: (Constant), risk, found, age, size

b. Dependent Variable: roa

Model Summaryb

\begin{tabular}{|l|r|r|r|r|r|}
\hline Model & $R$ & R Square & $\begin{array}{c}\text { Adjusted R } \\
\text { Square }\end{array}$ & $\begin{array}{r}\text { Std. Error of } \\
\text { the Estimate }\end{array}$ & $\begin{array}{c}\text { Durbin- } \\
\text { Watson }\end{array}$ \\
\hline 1 & $.542^{\mathrm{a}}$ & .294 & .279 & 1.029357 & 1.850 \\
\hline
\end{tabular}

a. Predictors: (Constant), risk, found, age, size

b. Dependent Variable: tobinsq

Tabel Hasil Uji Multikolinearitas

\begin{tabular}{|c|c|c|c|c|c|}
\hline \multirow{2}{*}{ Variabel } & \multicolumn{2}{|c|}{ Tolerance } & \multicolumn{2}{|l|}{ VIF } & \multirow{2}{*}{ Keterangan } \\
\hline & Tobins $Q$ & $R O A$ & Tobins $Q$ & $R O A$ & \\
\hline FOUND & 0.987 & 0.987 & 1.013 & 1.013 & Bebas Multikolinearitas \\
\hline SIZE & 0.798 & 0.798 & 1.254 & 1.254 & Bebas Multikolinearitas \\
\hline AGE & 0.855 & 0.855 & 1.170 & 1.170 & Bebas Multikolinearitas \\
\hline RISK & 0.931 & 0.931 & 1.074 & 1.074 & Bebas Multikolinearitas \\
\hline
\end{tabular}

Gambar Hasil Uji Normalitas P-Plot 
Normal P-P Plot of Regression Standardized Residual

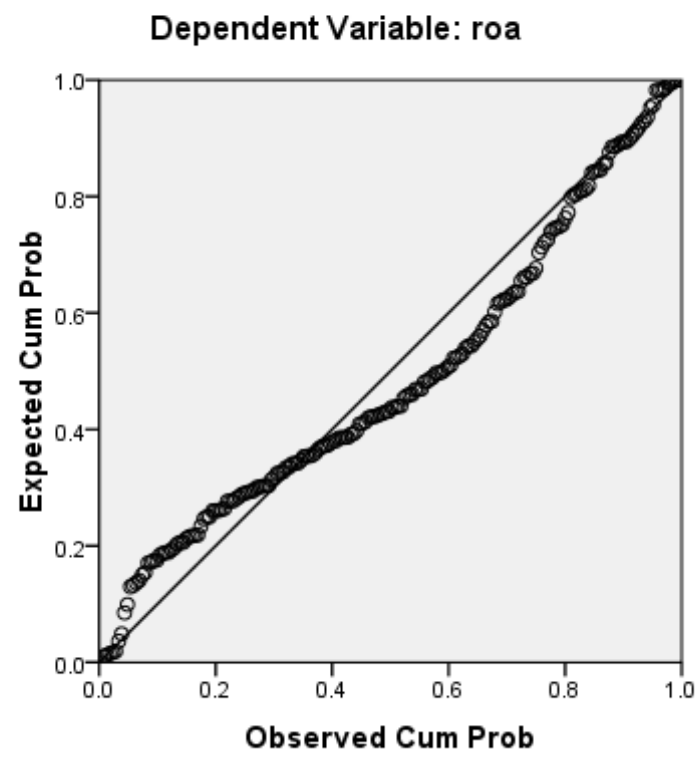

Normal P-P Plot of Regression Standardized Residual

Dependent Variable: tobinsq

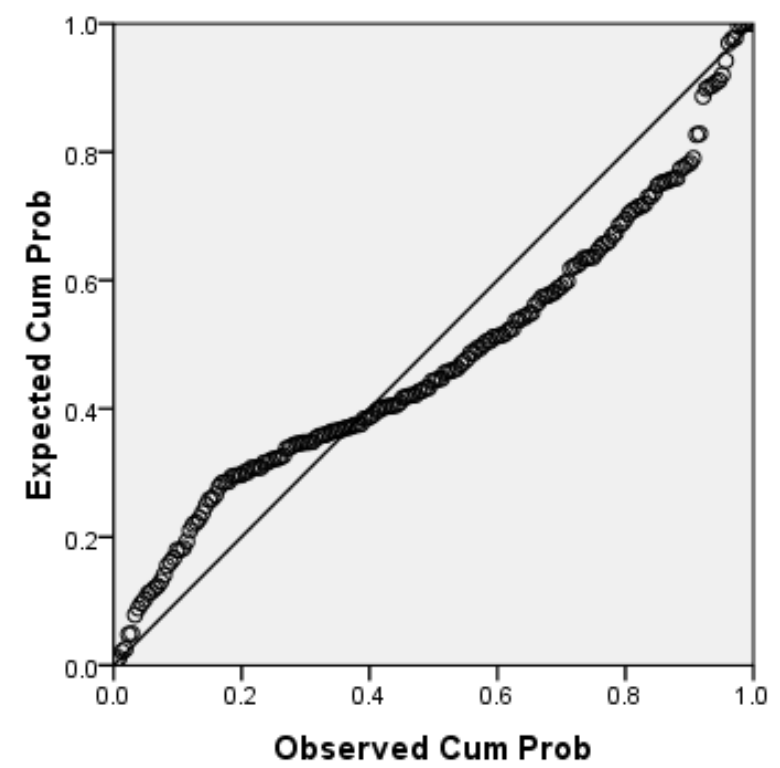

Hasil Uji Heteroskedastisitas 


\section{Dewi Ariani \\ Noorlaily Fitdiarini}
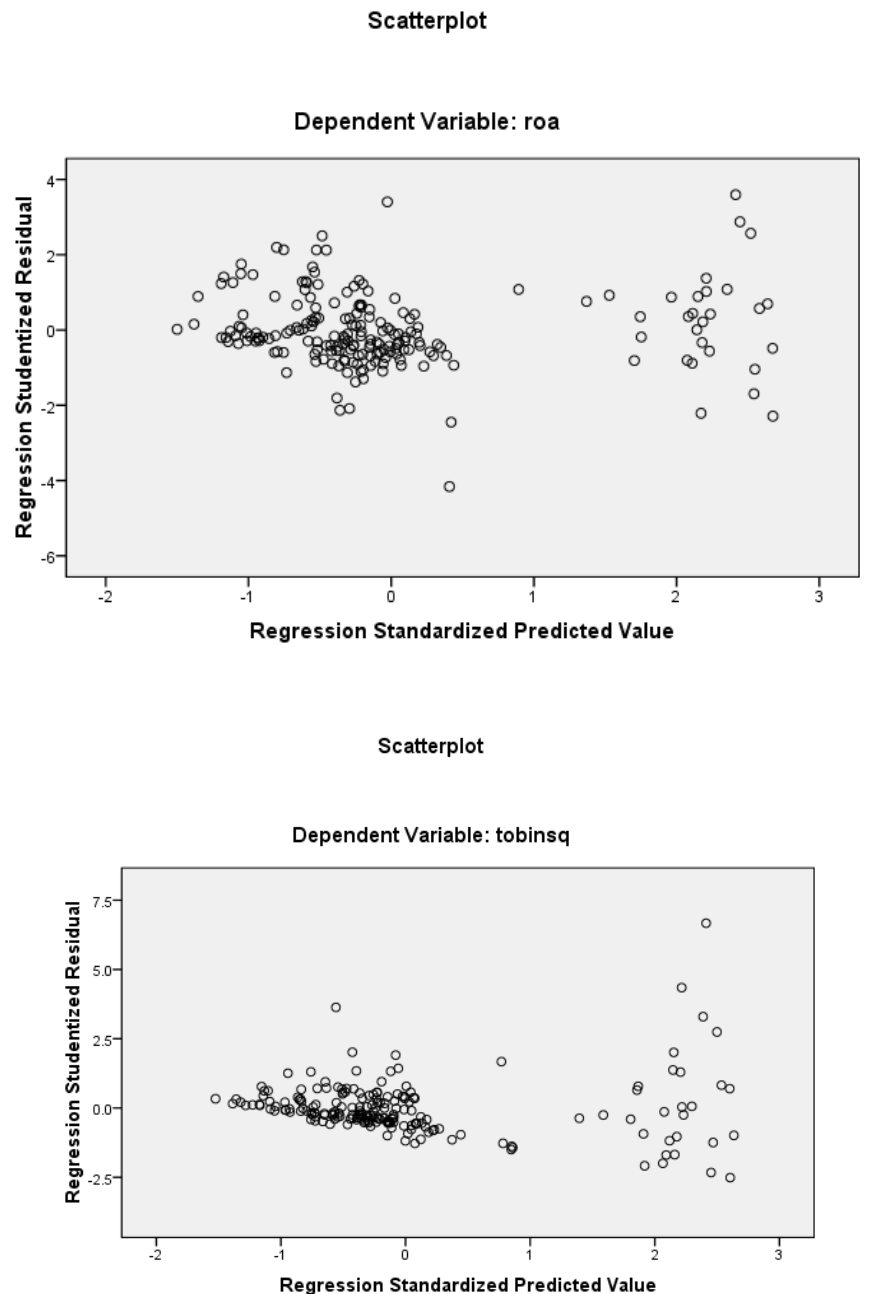

\section{Pengaruh Keluarga Pendiri terhadap Kinerja Keuangan (ROA)}

Hasil pada penelitian ini menunjukkan bahwa pada perusahaan keluarga, hubungan antara keterlibatan keluarga pendiri terhadap kinerja keuangan perusahaan adalah negatif signifikan. Hasil negatif menunjukkan bahwa perusahaan yang dikelola oleh keluarga pendiri akan menciptakan kinerja keuangan perusahaan yang lebih buruk dibanding perusahaan yang dikelola oleh keluarga non pendiri. Hasil penelitian ini mendukung hasil penelitian dari Sanjaya, (2014) akan tetapi bertolak belakang dengan penelitian yang dilakukan oleh Hamberg et al., (2013)

Tujuan utama perusahaan adalah meningkatkan nilai perusahaan, pendiri harus memiliki cara agar tujuan perusahaan tercapai. Salah satu cara agar tujuan perusahaan dapat tercapai yaitu pendiri harus menunjuk manajemen yang berkompeten sesuai dengan yang dibutuhkan perusahaan. Akan tetapi Susanto et al., (2007) menyatakan bahwa di Indonesia, pendiri memilih manajemen berdasarkan hubungan keluarga bukan berdasarkan kompetensi yang dimiliki manajemen. Manajemen yang tidak berkompeten tersebut tidak dapat mengelola biaya secara efektif dan efisien sehingga dapat mengurangi laba yang dihasilkan perusahaan.

\subsubsection{Pengaruh ukuran perusahaan terhadap kinerja keuangan (ROA)}


Hasil pada penelitian ini menunjukkan bahwa pada perusahaan keluarga, hubungan antara ukuran perusahaan terhadap kinerja keuangan perusahaan adalah positif signifikan. Hasil positif menunjukkan bahwa semakin besar ukuran perusahaan maka semakin besar pula kapasitas operasional yang mampu dilakukan oleh perusahaan sehingga dapat menghasilkan laba yang lebih besar dan dapat berdampak pada kinerja keuangan yang lebih baik pula.

Perusahaan besar umumnya memiliki kemudahan akses ke berbagai sumber dana dan mempunyai arus kas yang cenderung stabil dibandingkan perusahaan dengan ukuran kecil sehingga kemungkinan kebangkrutan yang dihadapi perusahaan besar akan lebih kecil jika dibandingkan dengan kemungkinan kebangkrutan yang dihadapi oleh perusahaan kecil. Hal tersebut dapat mengakibatkan net income yang dihasilkan perusahaan semakin besar. Hasil penelitian ini sejalan dengan Sanjaya (2014) dan King and Santor (2008), akan tetapi bertolak belakang dengan Hamberg et al., (2013).

\subsubsection{Pengaruh umur perusahaan terhadap kinerja keuangan (ROA)}

Hasil pada penelitian ini menunjukkan bahwa pada perusahaan keluarga, hubungan antara umur perusahaan terhadap kinerja keuangan adalah negatif signifikan. Dapat diartikan jika semakin tua umur perusahaan maka cenderung akan menurunkan hasil laba perusahaan keluarga yang berasal dari penggunaan aktiva perusahaan, sehingga kinerja keuangan perusahaan juga akan menurun. Hasil penelitian ini mendukung hasil penelitian dari Anderson and Reeb (2003) dan Schulze, et al. (2001).

Hasil penelitian bertolak belakang dengan penelitian Hamberg et al., (2013) yang menemukan bahwa perusahaan keluarga yang memiliki umur lebih lama dianggap lebih berpengalaman dan lebih cakap dalam menjalankan bisnisnya. Hal tersebut membuat perusahaan dengan umur yang lebih lama dapat menghasilkan kinerja keuangan yang lebih baik dibanding dengan perusahaan yang baru berdiri.

Hasil penelitian ini menunjukkan arah negatif karena menurut teori life cycle semakin lama umur perusahaan maka perusahaan akan memasuki tahap decline atau penurunan, sehingga penjualan dan keuntungan yang diterima perusahaan akan mengalami penurunan. Menurut teori siklus hidup perusahaan yang disebutkan oleh Adizes (1989) jika perusahaan telah memasuki siklus prime jika tidak dikontrol dan tidak adanya inovasi yang dilakukan oleh perusahaan maka akan menyebabkan perusahaan kalah dengan pesaing yang dapat mengakibatkan turunnya penjualan atau penyediaan jasa yang dapat berdampak pada turunnya kinerja keuangan perusahaan.

\subsubsection{Pengaruh risiko perusahaan terhadap kinerja keuangan (ROA)}

Hasil pada penelitian ini menunjukkan bahwa pada perusahaan keluarga, hubungan antara risiko yang dimiliki perusahaan terhadap kinerja kevangan adalah negatif tidak signifikan. Hasil yang tidak signifikan menunjukkan bahwa besar kecilnya kinerja keuangan tidak dipengaruhi oleh besar kecilnya risiko yang dimiliki perusahaan. Arah yang negatif menunjukkan bahwa semakin tinggi risiko yang dimiliki perusahaan maka semakin kecil kinerja keuangan yang dihasilkan oleh perusahaan.

Risiko yang dimiliki perusahaan ada dua yaitu sistematis dan tidak sistematis. Ketika perusahaan tidak dapat mengelola risiko sistematis maka perusahaan akan mengeluarkan biaya yang lebih besar untuk menangani risiko tersebut sehingga akan menurunkan laba perusahaan.

\section{Pengaruh keluarga pendiri terhadap nilai pasar perusahaan (Tobins $Q$ )}

Hasil pada penelitian ini menunjukkan bahwa keterlibatan keluarga pendiri dalam pengelolaan perusahaan berpengaruh negatif signifikan terhadap nilai pasar perusahaan (Tobins Q). Hal tersebut berarti 


\section{Dewi Ariani \\ Noorlaily Fitdiarini}

bahwa jika perusahaan dimiliki dan dikelola oleh keluarga pendiri maka akan menghasilkan nilai pasar perusahaan yang lebih kecil dibanding jika perusahaan dimiliki dan dikelola oleh keluarga non pendiri. Hasil penelitian ini mendukung penelitian yang dilakukan oleh Schulze, et al. (2001) akan tetapi bertolak belakang dengan Hamberg et al., (2013)

Tujuan utama perusahaan adalah meningkatkan nilai perusahaan, pendiri harus memiliki cara agar tujuan perusahaan tercapai. Salah satu cara agar tujuan perusahaan dapat tercapai yaitu pendiri harus menunjuk manajemen yang berkompeten sesuai dengan yang dibutuhkan perusahaan. Akan tetapi Susanto et al., (2007) menyatakan bahwa di Indonesia, pendiri memilih manajemen berdasarkan hubungan keluarga bukan berdasarkan kompetensi yang dimiliki manajemen. Manajemen yang tidak berkompeten tersebut tidak dapat mengelola biaya secara efektif dan efisien sehingga dapat mengurangi laba yang dihasilkan perusahaan. Perusahaan yang memiliki kinerja keuangan yang buruk akan mendapat nilai negatif dari investor karena dianggap tidak membawa keuntungan yang besar bagi investor sehingga lama kelamaan nilai pasar akan turun.

\section{Pengaruh ukuran perusahaan terhadap nilai pasar perusahaan (Tobins Q)}

Hasil pada penelitian ini menunjukkan bahwa pada perusahaan keluarga, pengaruh antara ukuran perusahaan terhadap nilai pasar perusahaan adalah positif signifikan. Hal ini menunjukkan bahwa semakin besar ukuran perusahaan maka akan semakin besar pula nilai pasar perusahaan (Tobins Q). Hasil penelitian ini sejalan dengan penelitian yang dilakukan oleh Villalonga and Amit (2006), akan tetapi bertolak belakang dengan Hamberg et al., (2013) yang menemukan bahwa perusahaan keluarga yang memiliki ukuran lebih besar, tidak memiliki nilai perusahaan lebih baik dibanding dengan perusahaan kecil.

Hasil penelitian ini menunjukkan arah positif signifikan karena semakin besar ukuran perusahaan maka dapat menghasilkan nilai pasar perusahaan yang besar pula. Karena investor meyakini bahwa semakin besar total asset yang dimiliki perusahaan maka kemampuan atau kapasitas perusahaan dalam melakukan produksi atau menyediakan jasa semakin besar, sehingga dapat menghasilkan keuntungan yang lebih besar. Selain itu, semakin tinggi total aset maka semakin tinggi pula kinerja keuangan yang dimiliki perusahaan. Semakin tinggi dan baik kinerja keuangan perusahaan maka semakin mudah untuk mendapatkan pendanaan sehingga lebih mudah dalam menghasilkan laba. Kumar, Rajan dan Zingales (2001) menjelaskan berdasarkan teori critical resources, yang menyebutkan bahwa semakin besar aktiva yang dimiliki perusahaan, menunjukkan semakin besar perusahaan sehingga semakin tinggi kinerja keuangan yang dimiliki. Hal tersebut membuat investor memiliki peluang besar untuk mendapatkan keuntungan sehingga dapat menarik minat investor yang akan berdampak pada naiknya nilai pasar perusahaan.

\section{Pengaruh umur perusahaan terhadap nilai pasar perusahaan (Tobins $Q$ )}

Hasil pada penelitian ini menunjukkan bahwa pada perusahaan keluarga, hubungan antara umur perusahaan terhadap nilai pasar perusahaan adalah negatif signifikan. Hal ini menunjukkan bahwa semakin tua umur perusahaan maka kemampuan untuk menghasilkan nilai pasar semakin menurun. Hasil penelitian ini konsisten dengan penelitian yang dilakukan oleh Anderson and Reeb (2003), King and Santor (2008), Villalonga and Amit (2006) dan Pukthuanthong (2013), yang menemukan bahwa umur perusahaan berpengaruh negatif terhadap nilai pasar perusahaan (Tobins Q). Menurut teori life cycle semakin lama umur perusahaan maka 
perusahaan akan memasuki tahap decline atau penurunan, sehingga penjualan dan keuntungan yang diterima perusahaan akan mengalami penurunan. Menurut teori siklus hidup perusahaan yang disebutkan oleh Adizes (1989) jika perusahaan telah memasuki siklus prime jika tidak dikontrol dan tidak adanya inovasi yang dilakukan oleh perusahaan maka akan menyebabkan perusahaan kalah dengan pesaing yang dapat mengakibatkan turunnya penjualan atau penyediaan jasa. Hal tersebut membuat pemegang saham bukan pengendali mengurangi kepercayaannya pada perusahaan sehingga sedikit demi sedikit menarik kepemilikannya yang dapat menyebabkan turunnya nilai pasar perusahaan. Akan tetapi, hasil penelitian ini bertentangan dengan hasil temuan dari Hamberg et al., (2013) yang menemukan bahwa perusahaan kelvarga yang memiliki umur lebih lama dianggap lebih berpengalaman dan lebih cakap dalam menjalankan bisnisnya.

\section{Pengaruh risiko perusahaan terhadap nilai pasar perusahaan (Tobins $Q$ )}

Hasil pada penelitian ini menunjukkan bahwa pada perusahaan keluarga risiko yang dimiliki perusahaan berpengaruh negatif signifikan terhadap nilai pasar perusahaan. Hasil tersebut berarti bahwa semakin tinggi risiko yang dimiliki perusahaan maka kemampuan perusahaan dalam menciptakan nilai pasar perusahaan juga semakin kecil.

Risiko yang dimiliki perusahaan ada dua yaitu sistematis dan tidak sistematis. Ketika perusahaan tidak dapat mengelola risiko sistematis maka perusahaan akan mengeluarkan biaya yang lebih besar untuk menangani risiko tersebut sehingga akan menurunkan laba perusahaan. Investor akan berpikir ulang dan kehilangan minat untuk menanamkan modalnya pada perusahaan yang memiliki risiko terlalu besar sehingga akan menyebabkan turunnya nilai pasar perusahaan.

\section{SIMPULAN DAN SARAN}

Berdasarkan hasil penelitian dan hasil analisis data yang mengacu pada tujuan penelitian, hipotesis, dan model analisis, maka dapat disimpulkan bahwa :

1. Keluarga pendiri dan umur perusahaan berpengaruh negatif signifikan terhadap Return On Assets (ROA), ukuran perusahaan berpengaruh positif signifikan terhadap Return On Assets (ROA), risiko perusahaan berpengaruh negatif tidak signifikan terhadap Return On Assets (ROA).

2. Keluarga pendiri, umur dan risiko berpengaruh negatif signifikan terhadap Tobins $Q$ dan Ukuran perusahaan berpengaruh positif signifikan terhadap Tobins $Q$.

Berdasarkan penelitian yang telah dilakukan, maka penulis dapat memberikan beberapa saran sebagai berikut :

1. Dewan komisaris bank sebaiknya memerhatikan dan mengawasi persentase kepemilikan saham CEO karena besar kecilnya persentase kepemilikan saham CEO memengaruhi total risk (TR).

2. Regulator diharapkan dapat memantau kepatuhan bank dalam memenuhi aturan tentang jumlah minimal komisaris independen yang harus ada pada struktur dewan komisaris karena masih ada bank yang melanggar. 


\section{Dewi Ariani \\ Noorlaily Fitdiarini}

Adams, R., Almeida, H. and Ferreira, D. 2009. "Understanding the relationship between founder-CEO and firm performance", Journal of Empirical Finance, Vol. 16, pp. 136150.

Anderson, Ronald C., \& David M. Reeb. 2003. Founding-Family Ownership and Firm Performance: Evidence from the S\&P 500. Journal of Finance, 58, 1301-1328.

Andres, Christian. 2008. Family Ownership, Financing Constraints and Investment Decisions. Working Paper. University of Bonn.

Ariani, dewi dan Noorlaily Fitdiarini. 2015. "Peran Keluarga Pendiri dalam Menciptakan Kinerja Keuangan dan Nilai Pasar pada Perusahaan Keluarga di Indonesia", Program Studi S1 Manajemen Unair,92.

Arthurs, J.D. and Busenitz, L.W. (2003), "The boundaries and limitations of agency theory and stewardship theory in the venture capitalist/entrepreneur relationship", Entrepreneurship Theory \& Practice, Vol. 28, pp. 145163.

Brigham, F. Eugene \& Joul F. Houston. 1998. Manajemen Keuangan. Edisi Kedelapan. Terjemahan oleh Dodo Suharto dan Herman Wibowo. 2001. Jakarta: Erlangga.

Campbell, Kevin \& Minguez-Vera, Antonio. 2008. Gender Diversity in the Boardroom and Firm Financial Performance. Journal of Business Ethics, 83, 435-451.

Chu, Wenyi (2009), "Family ownership and firm performance: Influence of family management, family control, and firm size", National Taiwan University, Vol. 28, pp: 833-851.

Ghozali, Imam. 2006. Aplikasi Analisis Multivariate dengan program SPSS. Semarang: Universitas Diponegoro. Hamberg, Mattias., Egil Andre Fagerland and Kristoffer Kvamme Nilsen. 2013. "Founding-family firms and the creation of value: Swedish evidence", Journal of Managerial Finance, Vol. 39, No. 10, pp. 963-978.

He, L. (2008), "Do founders matter? A study of executive compensation, governance structure and firm performance", Journal of Business Venturing, Vol. 23, pp. 257-279.

Keputusan Direksi PT Bursa Efek Jakarta Nomor: Kep-305/BEJ/07-2004

King, Michael R, and Eric Santor (2008), " Family value: Ownership structure, performance and capital structure of Canadian firms", Journal of Banking and Finance, Vol. 32, pp. 2423-2432.

Kumar, Krishna B., Raghuram G. Rajan, and Luigi Zingales (2001), "What Determines Firm Size?", Working Paper, University of Chicago, No 496.

La Porta, R. 1999. Corporate Ownership Around The World. Journal of Finance, 54, 471-517.

Maury, Benjamin. 2006. "Family ownership and firm performance: Empirical evidence from Western European corporations", Journal of Corporate Finance, 12, 321-341.

Munisi Gibson and Trond Randoy (2013), "Corporate governance and company performance across SubSaharan African countries", Journal of Economics and Business, Vol. 70, pp. 92-110.

Pukthuanthong, Kuntara (2012), Does family ownership create or destroy value? Evidence from Canada". International Journal of Managerial Finance, Vol. 9 No. 1, pp. 13-48.

Ross, Stephen A., Randolph W. Westerfield, Bradford D. Jordan. 2013. "Fundamentals of Corporate Finance". New York: McGraw-HII Irwin. 
Ross, Stephen A., Randolph W. Westerfield, Bradford D. Jordan. 2009. Pengantar Keuangan Perusahaan. Jakarta: Salemba Empat.

Sanjaya, I Putu Sugiartha (2014), "keluarga sebagai pemilik ultimat dan kinerja perusahaan", Universitas Atma Jaya Yogyakarta

Schulze, William S, Michael H. Lubaktin, Richard N. Dino, and Ann K. Buchholtz (2001), "Agency Relationships in Family Firms: Theory and Evidence", Organization Science, Vol. 12 No. 2, pp. 99-116.

Shleifer, Andrei and Robert W. Vishny (1986) "Large Shareholders and Corporate Control", The Journal of Political Economy, Vol. 94 pp: 461-488.

Shleifer, Andrei and Robert W. Vishny (1997) "A Survey of Corporate Governance", , The Journal of Finance, Vol. 52, pp: 737-783.

Sudana, I Made. 2011. Manajemen Keuangan. Surabaya: Erlangga.

Susanto, A.B., Himawan Wijanarko, Patricia Susanto, dan Suwahjuhadi Mertosono. 2007. The Jakarta Consulting Group on Family Business. Jakarta: The Jakarta Consulting Group.

Villalonga, B. and Amit, R. (2006), "How do family ownership control and management affect firm value?" Journal of Financial Economics, Vol. 80, pp. 385-417.

http://csr.bankmandiri.co.id/power-lunch-tantangan-perusahaan-keluarga-di-era-bisnis-modern/ www.idx.co.id 